Those Were the Days 



\section{Those Were the Days}

\section{Why All in the Family Still Matters}

JIM CULLEN

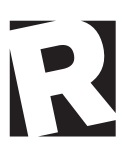

Rutgers University Press

New Brunswick, Camden, and Newark, New Jersey, and London 
Library of Congress Cataloging-in-Publication Data

Names: Cullen, Jim, 1962- author.

Title: Those were the days : why All in the family still matters /

Jim Cullen.

Description: New Brunswick : Rutgers University Press, 2020. | Includes bibliographical references and index. | Summary: "All in the Family; history of the show-why it matters now. How it was progressive for its time" - Provided by publisher.

Identifiers: LCCN 2019012948| ISBN 978197880578I (cloth) |

ISBN 9781978805774 (paperback)

Subjects: LCSH: All in the family (Television program)

Classification: LCC PN1992.77.A483 C85 2020 | DDC 791.45/72-dc23

LC record available at https://lccn.loc.gov/2019012948

A British Cataloging-in-Publication record for this book is available from the British Library.

Copyright $\odot 2020$ by Jim Cullen

All rights reserved

No part of this book may be reproduced or utilized in any form or by any means, electronic or mechanical, or by any information storage and retrieval system, without written permission from the publisher. Please contact Rutgers University Press, 106 Somerset Street, New Brunswick, NJ 0890 . The only exception to this prohibition is "fair use" as defined by U.S. copyright law.

@ The paper used in this publication meets the requirements of the American National Standard for Information Sciences-Permanence of Paper for Printed Library Materials, ANSI Z 39.48-1992.

www.rutgersuniversitypress.org

Manufactured in the United States of America 
For Wally Levis

Left, Right, and Centered 
